\title{
INCLUSION OF EXTRUDED GRASS PEA, LATHYRUS SATIVUS SEED MEAL IN COMPOUND DIETS FOR ROHU, LABEO ROHITA (HAMILTON, 1822) FINGERLINGS
}

\author{
Sarita RAMACHANDRAN, Arun Kumar RAY*
}

Fisheries Laboratory, Department of Zoology, Visva-Bharati University, Santiniketan, India

Ramachandran S., Ray A.K., 2004. Inclusion of extruded grass pea, Lathyrus sativus seed meal in compound diets for rohu, Labeo rohita (Hamilton, 1822) fingerlings. Acta Ichthyol. Piscat. 34 (2): 205-218.

Background. Grass pea, Lathyrus sativus is a widely available grain legume that contains a variety of anti-nutritional factors (ANFs). The aim of the present study was to determine the effects of feeding rohu, Labeo rohita, fingerlings with diets containing raw or extruded grass pea seed meal on growth, feed utilization efficiency, and carcass composition.

Material and methods. Extrusion of finely ground grass pea seeds was performed in a twin-screw extruder at $130^{\circ} \mathrm{C}$ and $400 \mathrm{rpm}$. Six isonitrogenous $(35 \%$ crude protein approximately) and isocaloric $\left(16547.7 \mathrm{~J} \cdot \mathrm{g}^{-1}\right)$ diets were formulated incorporating raw and extruded grass pea seed meal at 20,30 , and $40 \%$ levels by weight into a fish meal based control diet. The diets were fed to rohu fingerlings in triplicate treatments at the rate of $3 \%$ of body weight for 60 days and fish performance in terms of growth, apparent protein digestibility (APD), and carcass composition was studied.

Results. Extrusion of grass pea seed meal was effective in significantly reducing the ANFs, such as tannins (77\%), trypsin inhibitor (below detection limit), and $\beta$-ODAP $(46.09 \%)$. Phytic acid and nutrient components were not affected by extrusion. In terms of growth response, FCR and PER, $40 \%$ extruded grass pea meal incorporated diet resulted in significantly $(P<0.05)$ the best performance of rohu fingerlings. The APD values obtained for extruded seed meal incorporated diets were significantly higher in comparison to those for non-extruded ones. The carcass protein and lipid contents increased over the initial value in all dietary treatments with no significant differences in fish fed diets containing extruded grass pea seed meal.

Conclusion. Extrusion is an effective treatment to reduce/eliminate the ANFs in legumes. Improved growth, feed utilization efficiencies, and APD in rohu fingerlings indicate that extrusion processing is also effective in improving the nutritional characteristics of grass pea.

Key words: extrusion, grass pea, anti-nutritional factors, diets, growth, feed utilization, Labeo rohita fingerlings.

* Correspondence: Prof. Dr Arun Kumar Ray, Fisheries Laboratory, Department of Zoology, Visva-Bharati University, Santiniketan 731235, India, e-mail: arun_rayl@ rediffmail.com 


\section{INTRODUCTION}

Grass pea (Lathyrus sativus) is one of the important legumes of nutritional interest in countries like Bangladesh, India and Ethiopia (Yigzaw et al. 2001). It is rich in protein, about 20 to $32 \%$ (Castell et al. 1994) and used for human and animal consumption. However, it contains a large number of anti-nutritional substances, which limit its free nutritional utilization in monogastric animals (Hanbury et al. 2000) and humans (Troszyńska et al. 1993, Grela et al. 2001). The most frequently occurring anti-nutritional substances in grass pea are protease and amylase inhibitors, lectins, tannins, saponines, alkaloids, phytates, and lathyrogens (Sarma and Padmanaban 1969, Lambein et al. 1993). Although there is report on its use in broiler diets (Tadelle et al. 2003), no information is available demonstrating the potential use of grass pea in compound diets for fish.

The degree of processing of plant ingredients is known to be important in reducing the level and activity of several anti-nutritional factors as well as improving availability of nutrients to fish (Tacon 1997, Gouveia and Davies 2000). Attempts to increase the utilization of legumes have employed a wide range of processing techniques including extrusion cooking (Alonso et al. 2000, Gouveia and Davies 2000, Marzo et al. 2002, Venou et al. 2003). Extrusion cooking is now widely used to improve the nutritive value of legumes, primarily as a mean of reducing the level of heat-labile, non-nutritive compounds. However, little information is available on the effect of this processing method on the nutritive value of plant ingredients in compound diets for fish. An extruded pea seed meal and co-extruded product of rapeseed and peas (colzapro) were evaluated for rainbow trout and tilapia by Gomes et al. (1993, 1995) and Fontaínhas-Fernandes et al. (1997), respectively, with good results. The present investigation was designed to evaluate the effects of feeding rohu, Labeo rohita (Hamilton, 1822) fingerlings with diets containing raw or extruded grass pea meals on growth, feed utilization efficiency and carcass composition.

\section{MATERIALS AND METHODS}

Extrusion of Lathyrus seed meal

Extrusion of finely ground grass pea seeds was performed in a Twin-Screw Extruder (Basic Technology India). The extruder was operated at $400 \mathrm{rpm}$ and the temperature was set at $130^{\circ} \mathrm{C}$. Moisture content of the sample was increased to $12 \%$ by adding water.

Experimental diets

Two sets of approximately isonitrogenous (35\% crude protein) and isocaloric (16 $547.7 \mathrm{~J} \cdot \mathrm{g}^{-1}$ ) experimental diets were formulated using either raw (diets D1 to D3) or extruded (diets D4 to D6) grass pea seed meal at 20,30, or $40 \%$ levels by weight. A diet containing fish meal as the main protein source was used as the control diet (RD). To each of the formulated diet, $1 \%$ chromic oxide was added as an external 
digestibility marker. All the diets were prepared in pelleted form using $0.5 \%$ carboxymethylcellulose as a binder (Tables 1,2). The pellets were sun dried for a few days and crumbled prior to feeding.

Experimental Design

The feeding trial was conducted in flow-through 90-1 circular fibreglass tanks. Rohu, Labeo rohita fingerlings were obtained from a local fish seed dealer and acclimated to the laboratory conditions for 15 days and fed with a $1: 1$ mixture of rice bran and mustard oil cake prior to commencement of the experiment. Rohu fingerlings (mean weight $2.04 \pm 0.21 \mathrm{~g}$ ) were randomly distributed at the rate of 15 fish per tank with three replications for each treatment. Each experimental tank was supplied with non-chlorinated water from a deep tube well with continuous aeration. All the fish were fed once a day at a fixed feeding rate of $3 \%$ body weight per day for 60 days. The quantity of feed given was readjusted every 15 th day after weighing the fish. To determine the feed consumption, any leftover feed was collected $6 \mathrm{~h}$ after each feeding and weighed after oven drying. The faecal samples were collected everyday in the morning by siphoning $17 \mathrm{~h}$ after removal of the uneaten feed following the "immediate pipetting" method outlined by Spyridakis et al. (1989), from three replicates of each dietary treatment. The faeces naturally released by the fish could be easily detected and were immediately removed from the water with a glass cannula. At the termination of the 60-day experiment the fish from each replicate were weighed and analysed for carcass composition.

The water quality parameters from each tank were monitored each week throughout the experimental period. The ranges of water quality parameters were: temperature, $29-32^{\circ} \mathrm{C}$; $\mathrm{pH} 7-7.8$; dissolved oxygen, $4.6-5.4 \mathrm{mg} \cdot \mathrm{1}^{-1}$; and alkalinity, $155-165 \mathrm{mg} \cdot \mathrm{l}^{-1}$.

Chemical analyses and data collection

Proximate composition of feed ingredients, experimental diets, faecal samples, and fish carcass were analysed following standard methods (Anonymous 1990) as follows: moisture was determined by oven drying at $105^{\circ} \mathrm{C}$ for $24 \mathrm{~h}$; crude protein (Nitrogen $\times$ 6.25) by micro Kjeldahl digestion, and distillation after acid digestion using a Kjeltec 1026 Distilling Unit together with a Tecator Digestion System (Tecator, Sweden); lipid was determined by extracting the residue with $40-60^{\circ} \mathrm{C}$ petroleum ether for $7-8$ $\mathrm{h}$ in a Soxhlet apparatus; crude fibre was determined as loss on ignition of dried lipidfree residues after digestion with $1.25 \% \mathrm{H}_{2} \mathrm{SO}_{4}$ and $1.25 \% \mathrm{NaOH}$ using Fibertec System 2021, (Foss Tecator, Sweden); and ash was determined by combustion at $550^{\circ} \mathrm{C}$ in a muffle furnace to constant weight. Nitrogen-free extract (NFE) was computed by taking the sum of values for crude protein, crude lipid, crude fibre, and moisture and subtracting this from 100 (Maynard et al. 1979). Five fish from each aquarium were sampled at the termination of the feeding experiment, and the whole body was analysed for moisture, crude protein, crude lipid, and ash following the aforementioned methods. Chromic oxide in the diets and faecal samples was 


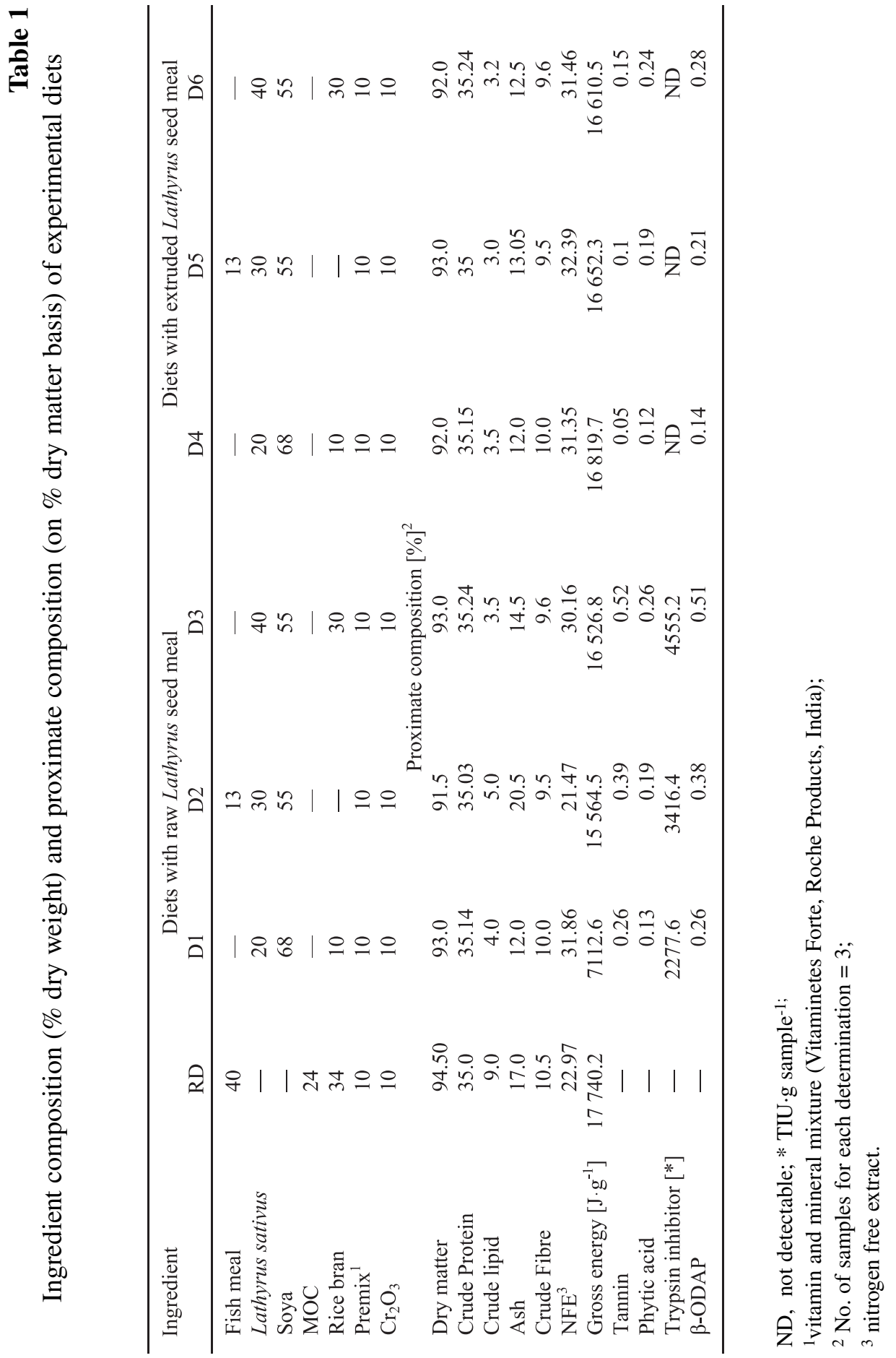


estimated following the method of Bolin et al. (1952). Tannin content in both raw and extruded grass pea seed meal was determined using Folin-Denis reagent (Schanderi 1970). Phytic acid content was determined according to Wheeler and Ferrell (1971).

Table 2

Proximate composition of feed ingredients [\% dry matter]

\begin{tabular}{lccccc}
\hline Parameter & $\begin{array}{c}\text { Fish } \\
\text { meal }\end{array}$ & $\begin{array}{c}\text { Soya bean } \\
\text { meal }\end{array}$ & Rice bran & $\begin{array}{c}\text { Raw } \\
\text { L. sativus }\end{array}$ & $\begin{array}{c}\text { Extruded } \\
\text { L. sativus }\end{array}$ \\
\hline Moisture & 2.26 & 6.5 & 4.45 & 6.5 & 6.5 \\
Dry matter & 97.04 & 93.50 & 95.55 & 93.50 & 93.50 \\
Crude Protein & 58.50 & 49.79 & 13.0 & 21.45 & 21.45 \\
Crude lipid & 8.91 & 3.2 & 5.14 & 3.5 & 3.5 \\
Ash & 11.5 & 3.5 & 2.14 & 3.5 & 3.5 \\
Crude Fibre & 3.93 & 7.0 & 2.55 & 7.5 & 7.5 \\
NFE & 14.2 & 30.01 & 30.50 & 57.55 & 57.55 \\
Gross energy $\left[\mathrm{Jg}^{-1}\right]$ & 202.4 & 19162.7 & 14727.7 & 17447.3 & 17447.3 \\
\hline
\end{tabular}

NFE, nitrogen-free extract.

The content of neurotoxin, $\beta$-ODAP (beta-oxalyl-diamino-propionic acid) in grass pea seed meal was determined by spectrophotometric method of analysis developed by Rao (1978). Trypsin inhibitor in the Lathyrus seeds was quantified following the method of Kakade et al. (1974). The water quality parameters were monitored weekly (Anonymous 1985). Apparent protein digestibility (APD, \%), specific growth rate (SGR, \% per day), feed conversion ratio (FCR), protein efficiency ratio (PER), and apparent net protein utilization (ANPU, \%) were calculated using standard methods (Steffens 1989).

Statistical analysis

Statistical analysis of data was performed by analysis of variance (ANOVA) using Statistica software followed by Duncan's multiple range test (Duncan 1955).

\section{RESULTS}

The proximate compositions of feed ingredients and experimental diets are presented in Tables 1 and 2, respectively. The raw grass pea seed meal contained 1.3\% of tannin. The level of tannin in the ingredient could be reduced to $0.25 \%$ by extrusion cooking. Extrusion of grass pea seed meal did not affect the phytic acid content significantly (1.07 percentage point reduction). The trypsin inhibitor in the raw seed 
meal was estimated as $31.25 \mathrm{TIU} \cdot \mathrm{g}$ sample ${ }^{-1}$ protein whereas in the extruded seed meal the amount of trypsin inhibitor was below detection limit. Extrusion of grass pea seed meal also resulted in the reduction of $\beta$-ODAP contents by 46.09 percentage points (Table 3).

Table 3

Effect of extrusion on anti-nutritional factors in Lathyrus seeds

\begin{tabular}{ccc}
\hline Anti-nutritional factor & Raw Lathyrus seed & $\begin{array}{c}\text { Percent reduction of anti-nutritional } \\
\text { factors after extrusion }\end{array}$ \\
\hline Tannin [\%] & 1.3 & 77 \\
Phytic acid [\%] & 6.52 & 1.07 \\
Trypsin inhibitor [*] & 113.88 & 100 \\
$\beta$-ODAP [\%] & 1.28 & 46.09 \\
\hline
\end{tabular}

* Trypsin inhibitor unit per g sample

The growth performance and feed utilization efficiencies of rohu fingerlings in terms of \% weight gain, specific growth rate (SGR), feed conversion ratio (FCR), protein efficiency ratio (PER), apparent net protein utilization (ANPU), and apparent protein digestibility (APD) are presented in Table 4 . The performance of fish was affected significantly by both type and inclusion level of grass pea seed meal. The average final weight of the fish increased from the initial value in all dietary treatments. Rohu fingerlings fed diet D6 containing 40\% extruded seed meal had the highest weight gain which was significantly higher $(P<0.05)$ than those fed other experimental diets. The highest attainment in fish body weight, average \% live weight gain and SGR were recorded in the group of fish reared on D6 (40\% extruded seed meal incorporation). PER was highest in fish fed diet D6. FCR was best for fish fed diet D6 and worst for diet D3. Apparent protein digestibility (APD) value for all the diets was high, ranging from $75.25 \%$ to $86.80 \%$. However, APD values obtained with extruded seed meal were significantly higher as compared to those with raw seed meal incorporated diets $(P<0.05)$.

The data regarding proximate carcass composition of experimental fish before and after the experiment are depicted in Table 5. The deposition of protein and lipid in the carcass of experimental fish increased over the initial value in all dietary treatments. Although highest accumulation of carcass protein was recorded in the group of fish reared on diet D5 and D6, the values were not significantly different $(P>0.05)$. Highest lipid accumulation occurred in fish fed diet D5. 


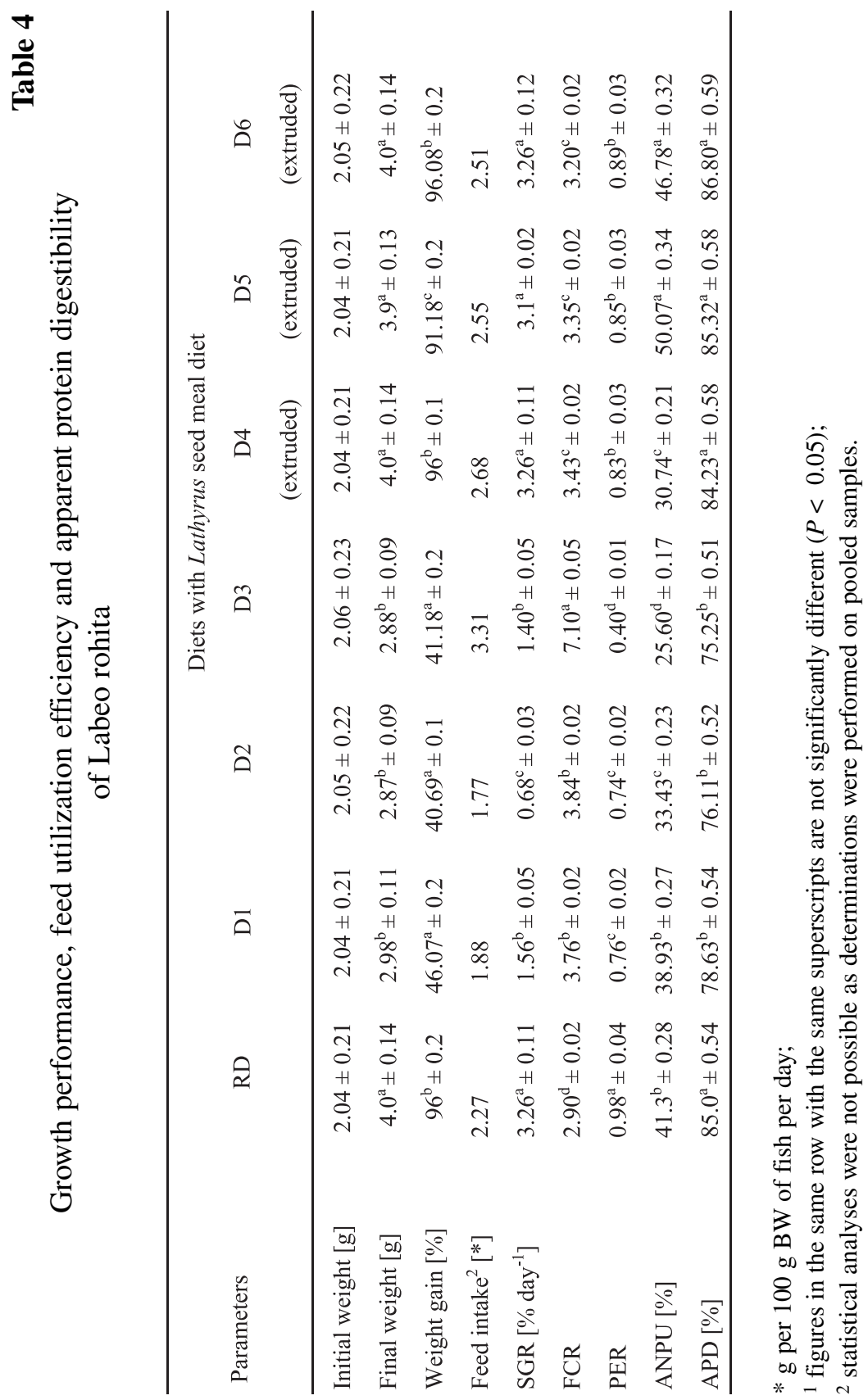


Table 5

Proximate carcass composition [\% wet weight] of the experimental fish at the start and end of the 60-day feeding experiment; data are mean values $\pm s(n=3)$

\begin{tabular}{lllll}
\hline & & \multicolumn{2}{c}{ Carcass composition } & \\
& Moisture & Crude protein & Crude lipid & Ash \\
\hline Initial & $78.7^{\mathrm{a}} \pm 0.54$ & $11.2^{\mathrm{d}} \pm 0.08$ & $2.0^{\mathrm{d}} \pm 0.01$ & $4.0^{\mathrm{b}} \pm 0.03$ \\
RD & $75.0^{\mathrm{a}} \pm 0.51$ & $14.0^{\mathrm{c}} \pm 0.09$ & $2.1^{\mathrm{c}} \pm 0.01$ & $4.4^{\mathrm{b}} \pm 0.02$ \\
D1 & $75.1^{\mathrm{a}} \pm 0.51$ & $15.5^{\mathrm{c}} \pm 0.1$ & $2.0^{\mathrm{d}} \pm 0.008$ & $4.9^{\mathrm{a}} \pm 0.03$ \\
D2 & $76.0^{\mathrm{a}} \pm 0.51$ & $15.6^{\mathrm{c}} \pm 0.1$ & $1.98^{\mathrm{d}} \pm 0.02$ & $4.3^{\mathrm{b}} \pm 0.03$ \\
D3 & $74.0^{\mathrm{a}} \pm 0.50$ & $17.4^{\mathrm{b}} \pm 0.12$ & $2.1^{\mathrm{c}} \pm 0.01$ & $3.0^{\mathrm{d}} \pm 0.02$ \\
D4 & $73.0^{\mathrm{a}} \pm 0.49$ & $18.0^{\mathrm{b}} \pm 0.12$ & $2.5^{\mathrm{c}} \pm 0.02$ & $3.2^{\mathrm{c}} \pm 0.02$ \\
D5 & $77.0^{\mathrm{a}} \pm 0.52$ & $20.0^{\mathrm{a}} \pm 0.13$ & $2.6^{\mathrm{b}} \pm 0.02$ & $3.1^{\mathrm{c}} \pm 0.02$ \\
D6 & $74.0^{\mathrm{a}} \pm 0.51$ & $19.0^{\mathrm{a}} \pm 0.13$ & $2.3^{\mathrm{c}} \pm 0.02$ & $3.4^{\mathrm{c}} \pm 0.02$ \\
\hline
\end{tabular}

Figures in the same column with the same superscripts are not significantly different $(P<0.05)$.

\section{DISCUSSION}

In the present study, the extruded grass pea, Lathyrus sativus seed meal proved to be a supplementary ingredient in formulated diets for rohu, Labeo rohita fingerlings. It is evident from this study that extruded grass pea seed meal could be incorporated up to $40 \%$ level in formulated diets for rohu fingerlings without affecting fish growth. Fish performance on diets containing similar levels of raw (non-extruded) grass pea was inferior to those reared on extruded ones. Davies (1998) reviewed the strategy of partial replacement of fish meal with alternative protein sources in practical diets for salmonid and marine finfish. This author emphasized that complex dietary and nutrient interactions resulting from anti-nutritional factors (ANFs), dietary fibre, and low availability of carbohydrate (as starch), collectively reduced the scope and potential for utilizing a wide range of raw materials or by-products of plant ingredients for different fish species. Adequate processing of plant ingredients, such as heat treatment, solvent extraction, flaking, or grinding are very beneficial techniques for improving the nutritional value of such ingredients in several fish species including carps (Tacon 1997). Evidence exists that the Indian major carp, Labeo rohita is particularly sensitive to quality and ANF content of plant materials (Mukhopadhyay and Ray 1996, 1999a, b).

Nutritionally, grass pea is protein-rich (Yigzaw et al. 2001), but the presence of variety of ANFs hinders its free utilization (Grela et al. 2001). The most frequently occurring ANFs in legumes are protease and amylase inhibitors, lectins, tannins, saponines, alkaloids, non-starch polysaccharides, vicine and convicine, phytates, and lathyrogens (Lambein et al. 1993, Riepe et al. 1995). Dietary tannins interfere with protein and dry matter digestibility by inhibiting protease and also forming 
indigestible complexes with dietary protein (Krogdahl 1989). There are reports of tannin toxicity in chickens (Vohra et al. 1966) and growth retardation and inhibition of digestive enzymes in fish (Hossain and Jauncey 1989, Mukhopadhyay and Ray 1996, 1999a, b, Bairagi et al. 2002, 2004, Maitra and Ray, 2003). Phytic acid acts as a chelator, forming protein and mineral-phytic acid complexes, the net result being reduced protein and mineral bioavailability (Spinelli et al. 1983, Hossain and Jauncey 1993). The grain of grass pea contains a neurotoxin, $\beta$-ODAP (beta-oxalyl-diaminopropionic acid), which causes paralysis of the lower/hind limbs in human and animals and general weakness in skeletal muscles (Grela et al. 2001). There is however, no report on the toxicity of $\beta$-ODAP in fish.

Extrusion processing did not affect the protein, carbohydrates (NFE), fibre and ash contents in grass pea meals. On the contrary, Marzo et al. (2002) reported significant reduction in the lipid content in extruded kidney beans. Extrusion processing greatly reduced the levels of ANFs, like tannin (77-percentage-point reduction), trypsin inhibitor (below detection limit) and $\beta$-ODAP (46.09-percentage-point) in grass pea meals. Phytic acid, however, remained unaffected due to extrusion. High extrusion temperatures can affect the molecular structure of condensed tannins and polyphenols. This chemical modification may alter tannins' solubility or chemical reactivity (Barroga et al. 1985). In the present study, extrusion cooking was also effective in lowering trypsin inhibitory activity below detection limit. Marzo et al. (2002) also demonstrated that trypsin inhibitory activity in kidney beans could be reduced by extrusion processing. Many ANFs such as protease inhibitors are heat labile and are thus denatured in this manner (Krogdahl et al. 1994). While studying the effects of different methods of treatment on $\beta$-ODAP content in grass pea, Tadelle et al. (2003) demonstrated that cooking at $90^{\circ} \mathrm{C}$ for 20 minutes was effective in 63.64percentage-point reduction of its level. During extrusion processing in our study, the temperature was set at $130^{\circ} \mathrm{C}$, which resulted in 46.09-percentage-point reduction of $\beta$-ODAP. Olney et al. (1976) observed that young mice showed symptoms of lathyrism and had $0.11 \mu \mathrm{mol} \cdot \mathrm{g}^{-1}$ ODAP, while adult mice exposed to similar grass pea showed trace or no ODAP and no symptom of lathyrism. During the present investigation, there was no visible sign of lathyrism in any of the fish fed raw grass pea incorporated diets. This could be due to feeding the period, which was not long enough for these effects to appear. Tekle Haimanot et al. (1993) indicated that lathyrism appears after a long period of feeding on grass pea. The growth performance and feed utilization efficiencies in rohu fingerlings fed extruded grass pea meal incorporated diets were significantly better than those fed diets containing raw grass pea meal at similar level of incorporation. Fish fed diet containing $40 \%$ extruded grass pea recorded better weight gain, SGR, and PER than the group of reared on a control diet containing fish meal as the protein source. The growth and feed utilization data obtained in the present study indicate that extrusion of grass pea seed meal improved the nutritive value of the ingredient. The maximum level of grass 
pea seed meal (40\%) amounted to only a partial substitution of fish meal protein. Gouveia and Davies (2000) observed slight improvement in overall performance of European seabass, Dicentrarchus labrax fed diets containing extruded pea seed meal although these were not significant. Venou et al. (2003) however, observed improved growth and feed and nutrient efficiencies in gilthead seabream, Sparus aurata fed diets containing extruded corn and wheat as carbohydrate sources at high inclusion levels (40\%). As stated earlier, one of the major factors involved in assessing nutritive value of plant ingredients for fish is the presence of several ANFs and high fibre content. In the present study, extrusion processing resulted in significant reduction of ANFs, like tannin, trypsin inhibitor, and $\beta$-ODAP in the grass pea seed meal. Since all the diets were isonitrogenous and the nutrient contents remained unaffected due to extrusion processing, the reduced growth of rohu fingerlings fed raw grass pea seed meal incorporated diets appeared to be due to the presence of ANFs. Extrusion technology leading to the production of expanded diets results in the partial or complete gelatinisation of the starch matrix in carbohydrate rich ingredients. This enables better availability of the starch to enzymatic attack within the gastrointestinal tract by amylase (Pongmaneerat and Watanabe 1993). In practical terms, higher digestibility coefficients are observed for such ingredients (Jeong et al. 1991, Pfeffer et al. 1991, Bergot 1993). The results of the present digestibility trial indicated high apparent digestibility of protein for dietary treatments containing extruded grass pea seed meal in comparison to those with raw (non-extruded) ones. Gouveia and Davies (2000), however, did not find any appreciable difference in digestibility coefficients for protein, lipid and carbohydrates by the inclusion of extruded dehulled pea seed meal in diets for juvenile European sea bass. Since the collection of faecal matter was done by pipetting, the risk of overestimation of digestibility values can not be ruled out. However, crumbling of the faeces can be minimized by adding an indigestible binder to the diets, which also binds the faeces (De la Noüe and Choubert 1986). In the present study, carboxymethylcellulose (CMC) was added to the experimental diets as a binder, which also helped in binding the faeces, leading to minimum leaching.

The growth rate of rohu fingerlings recorded in the present investigation was low in comparison to its growth in natural and farm conditions. The similar trend of growth has also been reported with other nutritional studies conducted on Indian major carps including rohu (Ravi and Devaraj 1991, Bairagi et al. 2002, 2004, Benkappa and Varghese 2003). A possible explanation could be that Indian major carps are sensitive to environmental conditions and do not attain maximum growth in a confined environment compared with other hardy species such as tilapia and common carp (Benkappa and Varghese 2003).

The proximate carcass composition data revealed no significant differences with regard to protein and lipid in fish fed diets containing extruded grass pea seed meal at different levels of incorporation, although their amount increased over the initial values irrespective of treatment of the test ingredient. Digestibility coefficient of 
protein reflected with respect to the carcass protein accretion of rohu fingerlings at the end of the experiment in accordance with the results of Gauveia and Davies (2000) in sea bass fed extruded pea seed meal incorporated diets.

\section{CONCLUSION}

The reduction in most of the ANFs in extruded grass pea seed meal indicates that extrusion cooking is an effective treatment to reduce the toxicity of raw legumes. Extrusion processing improved the nutritional characteristics of grass pea seed meal which is evident from improved growth and protein digestibility in rohu fingerlings fed extruded grass pea seed meal incorporated diets. Although the extruded grass pea meal was effective for rohu fingerlings, it is expected that this product will have obvious benefits and more stable nutritional value for productive diets for grow-out stages.

\section{ACKNOWLEDGEMENTS}

We are grateful to the Department of Science and Technology, Government of India (Project No. SP/SO/C-09/2000) for financial support. The generous gift of purified $\beta$-ODAP from Professor S.L.N. Rao, Lathyrus Technologies Pvt. Ltd., Hyderabad, India is gratefully acknowledged. We are also thankful to Dr S.K. Mukherjee, Basic Technology Pvt. Ltd., 2-2B Nundy Street, Kolkata-700029, India, for technical advice in extrusion processing.

\section{REFERENCES}

Alonso R., Aguirre A., Marzo F., 2000. Effects of extrusion and traditional processing methods on antinutrients and in vitro digestibility of protein and starch in faba and kidney beans. Food Chemistry 68: 159-165.

Anonymous, 1985. Standard methods for the examination of water and waste water. 16th edition. American Public Health Association (APHA), Washington, DC.

Anonymous, 1990. Official Methods of Analysis. 15th edition. Association of Official Analytical Chemists (AOAC), Washington, DC.

Bairagi A., Sarkar Ghosh K., Sen S.K., Ray A.K., 2002. Duckweed (Lemna polyrhiza) leaf meal as a source of feedstuff in formulated diets for rohu (Labeo rohita Ham.) fingerlings after fermentation with a fish intestinal bacterium. Bioresource Technology 85: 17-24.

Bairagi A., Sarkar Ghosh K., Sen S.K., Ray A.K., 2004. Evaluation of nutritive value of Leucaena leucocephala leaf meal inoculated with fish intestinal bacteria Bacillus subtilis and Bacillus circulans in formulated diets for rohu, Labeo rohita (Hamilton) fingerlings. Aquaculture Research 35: 436-446.

Barroga C.F., Laurena A.C., Mendozo M.T., 1985. Polyphenols in mung bean (Vigna radiate (L.) Wilczek): Determination and removal. Journal of Agriculture and Food Chemistry 33: 106-109.

Benkappa S., Varghese T.J., 2003. Isoleucine, leucine, and valine requirement of juvenile Indian major carp, Cirrhinus cirrhosus (Bloch, 1795). Acta Ichthyologica et Piscatoria 33: 161-172. 
Bergot F., 1993. Digestibility of native starches of various botanical origins by rainbow trout (Oncorhynchus mykiss). pp. 857-865. In: Kaushik S.J., Luquet P., (eds.) Fish nutrition in practice. INRA Editions, Paris.

Bolin D.W., King R.P., Klosterman E.W., 1952. A simplified method for the determination of chromic oxide $\left(\mathrm{Cr}_{2} \mathrm{O}_{3}\right)$ when used as an index substance. Science 116: 634-635.

Castell A.G., Cliplef R.L., Briggs C.J., Cambell C.G., Bruni J.E., 1994. Evaluation of lathyrus (Lathyrus sativus L) as an ingredient in pig starter and grower diets. Canadian Journal of Animal Science 74: 529-539.

Davies S.J., 1998. Towards the development of commercial aquafeeds with reduced dependency on marine protein resources. A nutritionist's perspective. Technological and nutritional aspects of safe feed production, Victam 98, 13-14 May 1998, Utrech, The Netherlands p. 16.

Duncan D.B., 1955. Multiple range and multiple F-tests. Biometrics 11: 1-42.

Fontaínhas-Fernandes A., Figueiredo-Fernandez A., Gomes E.F., Reis-Henriques M.A., Coimbra M.A., 1997. Replacement of fish meal by plant proteins in the diet of tilapia, Oreochromis niloticus : digestibility and growth performance. Third international symposium on research for aquaculture: fundamental and applied aspects, 24-27 August 1997, Barcelona, Spain p. 187.

Gomes E.F., Corraze G., Kaushik S.J., 1993. Effects of dietary incorporation of a coextruded plant protein (rapeseed and peas) on growth, nutrient utilization and muscle fatty acid composition of rainbow trout (Oncorhynchus mykiss). Aquaculture 113: 339-353.

Gomes E.F., Rema P., Kaushik S.J., 1995. Replacement of fish meal by plant proteins in the diets of rainbow trout (Oncorhynchus mykiss). Aquaculture 130: 177-186.

Gouveia A., Davies S.J., 2000. Inclusion of an extruded dehulled pea seed meal in diets for juvenile European sea bass (Dicentrarchus labrax). Aquaculture 182: 183-193.

Grela E.R., Studziński T., Matras J., 2001. Antinutritional factors in seeds of Lathyrus sativus cultivated in Poland. Lathyrus Lathyrism Newsletter 2: 101-104.

Hanbury C.D., White C.L., Mullan B.P., Siddique K.H.M., 2000. A review of the potential of Lathyrus sativus L. and L. cicera L. grain for use as animal feed. Animal Feed Science Technology 87: 1-27.

Hossain M.A., Jauncey K., 1989. Nutritional evaluation of some Bangladeshi oilseed meals as partial substitutes for fish meal in the diet of common carp, Cyprinus carpio L. Aquaculture and Fisheries Management 20: 255-268.

Hossain M.A., Jauncey K., 1993. The effects of varying dietary phytic acid, calcium and magnesium levels on the nutrition of common carp, Cyprinus carpio. pp. 705-715. In: Kaushik S.J., Luquet P., (eds.) Fish nutrition in practice. INRA Editions, Paris.

Jeong K.S., Takeuchi T., Watanabe T., 1991. Improvement of nutritional quality of carbohydrate ingredients by extrusion process in diets of red sea bream. Nippon Suisan Gakkaishi 57: 1543-1549.

Kakade M.J., Rackis I.J., McGheen J.E., Puski G., 1974. Determination of trypsin inhibitor activity of soy products : a collaborative analysis of an improved procedure. Cereal Chemistry 51: 376-382.

Krogdahl Å., 1989. Alternative protein sources from plants containing anti-nutrients affecting digestion in salmonids. pp. 253-261. In: Takeda M., Watanabe T., (eds.) Proceedings of the Third International Symposium in Feeding and Nutrition in Fish. Tokyo University of Fisheries, Tokyo. 
Krogdahl Å., Berg T., Olli J.J., 1994. Soybean proteinase inhibitors affect intestinal trypsin activities and amino acid digestibilities in rainbow trout (Oncorhynchus mykiss). Comparative Biochemistry Physiology A 107: 215-219.

Lambein F., Khan J.K., Kuo Y.-H., Campbell C.G., Briggs C.J., 1993 Toxins in the seedlings of some varieties of grass pea (Lathyrus sativus). Natural Toxins 1: 246-249.

Maitra S., Ray A.K., 2003. Inhibition of digestive enzymes in rohu, Labeo rohita (Hamilton), fingerlings by tannin: an in vitro study. Aquaculture Research 34: 93-95.

Marzo F., Alonso R., Urdaneta E., Arricibita F.J., Ibáñez F., 2002. Nutritional quality of extruded kidney bean (Phaseolus vulgaris L. var. Pinto) and its effects on growth and skeletal muscle nitrogen fractions in rats. Journal of Animal Science 80: 875-879.

Maynard L., Loosli J., Hintz H., Warner R., 1979. Animal Nutrition. 7th edition. McGraw Hill, New York.

Mukhopadhyay N., Ray A.K., 1996. The potential of sal (Shorea robusta) seed meal as a feedstuff in pelleted feed for Indian major carp, rohu, Labeo rohita (Hamilton), fingerlings. Aquaculture Nutrition 2: 221-227.

Mukhopadhyay N., Ray A.K., 1999a. Utilization of copra meal in the formulation of compound diets for rohu, Labeo rohita, fingerlings. Journal of Applied Ichthyology 15: $127-131$.

Mukhopadhyay N., Ray A.K., 1999b. Effect of fermentation on the nutritive value of sesame seed meal in the diets for rohu, Labeo rohita (Hamilton), fingerlings. Aquaculture Nutrition 5: 229-236.

De la Noüe J., Choubert G., 1986. Digestibility in rainbow trout: comparison of the direct and indirect methods of measurement. Progressive Fish Culturist 48: 190-195.

Olney J.W., Misra C.H., Rhee V., 1976. Brain and retinal damage from lathyrus exitotoxin, $\beta$-N-oxalyl-L-diaminopropionic acid. Nature 264: 659-661.

Pfeffer E., Beckmann-Toussaint J., Henrichfreise B., Jansen H.D., 1991. Effect of extrusion on efficiency of utilization of maize starch by rainbow trout (Oncorhynchus mykiss). Aquaculture 96: 293-303.

Pongmaneerat J., Watanabe T., 1993. Effect of extrusion on the utilization of soybean meal diets for rainbow trout. Nippon Suisan Gakkaishi 58: 1407-1414.

Rao S.L.N., 1978. A sensitive and specific colorimetric method for the determination of alpha, beta-ODAP, the Lathyrus sativus neurotoxin. Analytical Biochemistry 86: 386-395.

Ravi J., Devaraj K.V., 1991. Quantitative essential amino acid requirements for growth of Catla catla (Hamilton). Aquaculture 96: 281-291.

Riepe M., Spencer P.S., Lambein F., Ludolph A.C., Allen C.N., 1995. In vitro toxicological investigation of isoxazoline amino acids of Lathyrus sativus. Natural Toxins 11: 58-64.

Sarma P.S., Padmanaban G., 1969. Lathyrogens. pp. 267-291. In: Liener I.E., (ed.) Toxic constituents of plant foodstuffs. Academic Press, New York and London.

Schanderi S.H., 1970. Methods in Food Analysis. Academic Press, New York.

Spinelli J., Houle CR., Wekell J.C., 1983. The effect of phytates on the growth of rainbow trout (Salmo gairdneri) fed purified diets containing varying quantities of calcium and magnesium. Aquaculture 30: 71-83.

Spyridakis P., Metallier R., Gabaudan J., Riaza A., 1989. Studies on nutrient digestibility in European sea bass (Dicentrarchus labrax). I. Methodological aspects concerning faeces collection. Aquaculture 77: 61-70. 
Steffens W., 1989. Principles of Fish Nutrition. Ellis Horwood, Chichester.

Tacon A.G.J., 1997. Fish meal replacers: review of antinutrients within oilseeds and pulsesa limiting factor for the aquafeed green revolution? pp. 153-182. In: Tacon A., Basurco B., (eds.) Feeding tomorrow's fish. Vol. 22. Cahiers Options Méditerranéennes, Institut Agronomique Méditerranéen de Zaragoza, Spain.

Tadelle D., Alemu Y., Nigusie D., Peters K.J., 2003. Evaluation of processing methods on the feeding value of grass pea to broilers. International Journal of Poultry Science 2: 120-127.

Tekle Haimanot R., Abegaz B.M., Wuhib E., Kassina A., Kidane Y., Kebede N., Alemu T., Spencer P.S., 1993. Patterns of Lathyrus sativus (grass pea) consumption and oxalyl, $\beta$-diaminopropionic acid ( $\beta$-ODAP) content of food samples in the lathyrism endemic region of northwest Ethiopia. Nutrition Research 13: 1113-1126.

Troszyńska A., Honke J., Milczak M., Kozowska H., 1993. Antinutritional substances in lentil (Lens culinaris) and everlasing pea (Lathyrus sativus). Polish Journal of Food and Nutritional Science 2: 49-54.

Venou B., Alexis M.N., Fountoulaki E., Negas I., Apostolopoulou M., Castritsi-Cathariou I., 2003. Effect of extrusion of wheat and corn on gilthead sea bream (Sparus aurata) growth, nutrient utilization efficiency, rates of gastric evacuation and digestive enzyme activities. Aquaculture 225: 207-223.

Vohra P., Kratzer F.H., Joslyn M.A., 1966. The growth depressing and toxic effects of tannins to chicks. Poultry Science 46: 135-142.

Wheeler E.L., Ferrel R.E., 1971. A method for phytic acid determination in wheat and wheat fractions. Cereal Chemistry 48: 312-320.

Yigzaw Y., Gorton L., Akalu G., Solomon T., 2001. Fermentation of teff (Eragrostis tef), grass pea (Lathyrus sativus), and their mixtures: Aspects of nutrition and food safety. Lathyrus Lathyrism Newsletter 2: 8-10.

Received: 26 July 2004 Accepted: 3 November 2004 